\title{
Seizures and chest x-rays: can you Pott the diagnosis?
}

\author{
Nisha Ranganathan, ${ }^{1}$ Preya J Patel, ${ }^{2}$ Yasmin Pasha $^{3}$ \\ ${ }^{1}$ Royal Free Hospital, London, UK \\ ${ }^{2}$ Department of Cardiology, Royal Brompton Hospital, London, UK \\ ${ }^{3}$ Department of Gastroenterology, Hillingdon Hospital, London, UK
}

Correspondence to Dr Nisha Ranganathan, n.ranganathan13@gmail.com

\section{DESCRIPTION}

A 27-year-old Kenyan woman presented with collapse, and a 1 min episode of tonic-clonic jerking of her right arm and leg with no other symptoms. She denied any illicit drug use, and had been living in the UK for 10 months. A contrast-enhanced CT scan showed a ringenhancing lesion. An MRI to further characterise the lesion favoured a diagnosis of a tuberculoma. The initial chest x-ray was re-reviewed and having being initially reported as normal by the $\mathrm{A} \& \mathrm{E}$, medical and neurological teams, was found to show a paraspinal mass, extending from T7-T11 (figure 1). The patient was started on antituberculosis therapy and underwent further investigation with CT chest, abdomen and pelvis and MRI spine. Neurosurgical referral was sought; however, as there were no signs of cord-compression, no surgery was indicated. She subsequently made an uncomplicated recovery.

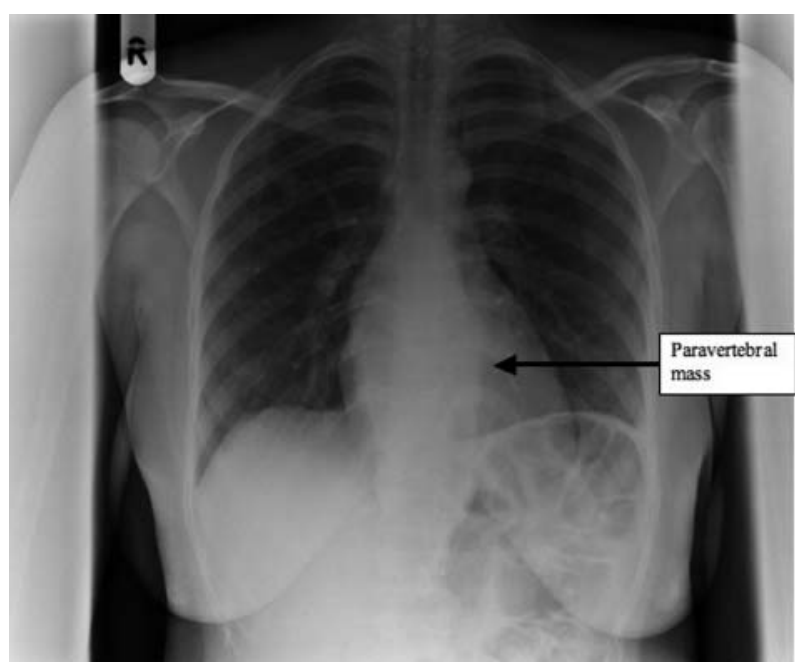

Figure 1 A large soft tissue density is projected behind the heart shadow on both sides of the spine in keeping with a paraspinal mass. The left margin of the density appears smooth and lobulated. No bony lesion is seen. 165x135mm (72 x $72 \mathrm{DPI})$.

\section{Learning points}

- Remember to review bony components of the radiograph, not just the lung fields.

- Spinal involvement may be the first manifestation of tuberculosis. ${ }^{1}$

- Have a high index of suspicion of tuberculosis in patients from endemic countries, who have had contact with someone from an endemic country, the immunocompromised, intravenous drug users, the homeless $^{2}$ and those who present with any of; fever, cough malaise, back pain, neurological symptoms or weight loss.

Competing interests None.

Patient consent Obtained.

\section{REFERENCES}

1. Turgut M. Spinal tuberculosis (Pott's disease): its clinical presentation, surgical management, and outcome. A survey study on 694 patients. Neurosurg Rev 2001;24:8-13.

2. Dye C, Floyd K, Uplekar M, World Health Organization. Global tuberculosis control report-surveillance, planning, finance. World Health Organization; 2008, Report No: WHO/HTM/TB/2008.393. 


\section{BMJ Case Reports}

This pdf has been created automatically from the final edited text and images.

Copyright 2012 BMJ Publishing Group. All rights reserved. For permission to reuse any of this content visit http://group.bmj.com/group/rights-licensing/permissions.

BMJ Case Report Fellows may re-use this article for personal use and teaching without any further permission.

Please cite this article as follows (you will need to access the article online to obtain the date of publication).

Ranganathan N, Patel PJ, Pasha Y. Seizures and chest x-rays: can you Pott the diagnosis?. BMJ Case Reports 2012;10.1136/bcr-2012-006666, Published XXX

Become a Fellow of BMJ Case Reports today and you can:

- Submit as many cases as you like

- Enjoy fast sympathetic peer review and rapid publication of accepted articles

- Access all the published articles

- Re-use any of the published material for personal use and teaching without further permission

For information on Institutional Fellowships contact consortiasales@bmjgroup.com

Visit casereports.bmj.com for more articles like this and to become a Fellow 